\title{
The Binding of Isaac and Historical Contextuality
}

Chayuta Deutsch

\section{Introduction}

One of the fundamental arguments raised in the context of biblical criticism is that the mores of the Bible do not meet the ethical standards of the postbiblical world. The examples cited are numerous and well-known. The Binding of Isaac (the Akedah) is an extreme case, accentuated by the central place it has received in historical and cultural consciousness.

Ethical arguments against the Akedah were voiced audibly during the twentieth century in nonreligious frameworks, but also previously within religious environments. The questions that have been asked (and are still being asked) about the Akedah, can be narrowed down to two major questions that relate to the passage itself. ${ }^{1}$ The first question regards the position of God: How could He command a father to slaughter his own son, and moreover, after the command had been retracted, how could He praise the willingness to obey it? The second question concerns the position of Abraham: How could he obey such a command without argument, especially in light of his previous negotiation with God to stop the destruction of Sodom? ${ }^{2}$

In fact, these questions receive initial validation from within the Bible itself, which condemns the child sacrifice prevalent in Canaanite culture. Examples of this condemnation be found in Jeremiah $(7: 31 ; 19: 5)$, Micah $(6: 6-7)$, and elsewhere. These verses augment the fundamental problem inherent to God's commandment to sacrifice Isaac: it could be identified, speciously, with the child sacrifice of the Canaanite cult of Molech. An example of such a verse can be found in Jeremiah 7:29-31: "For the Lord has spurned and cast off the brood that provoked His wrath. For the people of Judah have done what displeases $\mathrm{Me}$-declares the Lord. They have set up their abominations in the 
House which is called by My name, and they have defiled it. And they have built the shrines of Topheth in the Valley of Ben-hinnom to burn their sons and daughters in fire-which I never commanded, which never came to My mind."

In an illuminating article, Daniel Vainstub analyzes the custom of child sacrifice in Canaan in its various forms (both private and public sacrifice) and provides archeological evidence for its practice. Vainstub observes that "there are few cultures in which the adulation of God in its highest form is expressed by parents sacrificing their small children. Such a practice negates not only the instinct for acquiring property inherent to every human being, but also contradicts one of the strongest and most primal natural instincts, common to humans and animals - a mother's love for her child." ${ }^{3}$ He divides ancient sacrifice into two basic categories: sacrifice as an expression of thanksgiving or commitment, and sacrifice in the context of a public ceremony in a time of great danger to the community. He uses familiar verses to substantiate his claim that "the sacrifice of children to Molech was the most despicable of all the Canaanite abominations in the eyes of the zealous followers of God."

Against this backdrop, there emerges a third, very troubling question. It does not concern the interpretation of the verses but rather the use of the Akedah within the Jewish historical consciousness, as first expressed in the Jerusalem Talmud: "Rabbi Bibi Abba said in the name of Rabbi Yohanan, "Abraham said to God, "You know well that when you told me to sacrifice my son Isaac ... I suppressed my feelings and did your will. May it be your will, my God, that when the children of Isaac, my son, are in trouble and have no one to plead their cause, You will plead their cause."'”5

According to this passage, the Akedah is a seminal historical event. It is the paradigm, on the one hand, of a test that was passed, and whose rewards are reaped by the Jewish people throughout the generations, and, on the other hand, of a path of suffering that many Jews have travelled in the course of trials no less difficult than that of Abraham. This path begins with Hannah, ${ }^{6}$ who at the martyrdom of her seven sons called out to Abraham, "You built one altar; I have built seven!" It continues throughout the persecutions of the Diaspora culminating with the Holocaust, and ends with the sacrifice of sons on the altar of the wars fought to build the State of Israel.

My intention in this article is to briefly survey the different approaches to answering the ethical questions raised by the Akedah. Critique leveled from outside the world of faith is by nature subversive, rejecting the story and its images. Critique from within the religious world raises objections that usually culminate in resolution or apologetics rather than rejection. I will review some 
of the convoluted interpretations of the verses praising the deed proposed by almost every commentator who has addressed these questions. Above all, I will attempt to demonstrate that approaches to the Akedah in almost every case reflect the contemporary values and culture of the commentator. In the final section of the article I will apply the perspective of historical context to the story of the Akedah itself. This approach, despite the theological difficulties that it raises and its use in critical and antireligious forums that reject the sanctity of the Bible, has not, in my opinion, received the attention it deserves within the religious world.

\section{"External" Criticism: The Akedah as a "Black Bird"}

A deity who is prepared to put man to such a test is a very dubious deity.... What is the meaning of this unconditional loyalty of Abraham? Blind loyalties of this kind are what brought upon humanity the most horrific atrocities. (A. B. Yehoshua $)^{7}$

The writer A.B. Yehoshua is one of the most prominent of those who have spoken out vociferously against the Akedah in recent years. "The Akedah hovers over our history like a black bird," he wrote in an anthology on the subject of his novel Mr. Mani. "From my early childhood I have had a problem with this story, one of the seminal legends of the Jewish people. On the second day of Rosh Hashanah the story of the Akedah is read from the Torah and all the sounds of the Shofar and the many liturgical poems allude to it. The Akedah is the foundation of the religious covenant; it is the merit of the forefathers." 8 Yehoshua attempted to negate the charm and power of the act of the Akedah by means of a literary act. His novel Mr. Mani tells the story of a familial dynasty in whose past lies a terrible sin-the murder of a son by his father, described by the author as "an actualized Akedah." Yehoshua shaped the plot so that the murder is committed in the same place as the Akedah itself, on Mount Moriah, the site of the Temple in Jerusalem. The author has explained that his motivation in writing the story was to fight (!) against the myth of the Akedah and, in his words, "to negate the Akedah by realizing it." Yehoshua rejects the various exegetical solutions that follow the approach of Kierkegaard, ${ }^{10}$ and instead stresses that Christianity corrected the myth of the Akedah by replacing it with the ethically coherent myth of the crucifixion, in which the man-god sacrifices himself, not another, as an offering of atonement for human sin and to end human suffering. $\mathrm{He}$ argues that there are no subsequent references in the Bible to the story of 
the Akedah because "already then they were aware of the profound difficulties concerning this myth." Yehoshua's questions are better than his answers. ${ }^{11} \mathrm{His}$ interpretation of the biblical narrative, though influenced by Kierkegaard, is based on what he defines as a "secular" reading of the story.

Many others have written in the vein of this type of critique that does not hesitate to invalidate the biblical text. Hugo Bergmann, for example, believed moral qualms over the act of the Akedah to be ethically superior to the commandment itself. ${ }^{12}$ Following in his footsteps, Asa Kasher ${ }^{13}$ expressed preference for the model of the father-son relationship exemplified by David and Absalom over that of Abraham and Isaac. ${ }^{14}$ Other examples of this approach include the comment that the late Meretz MK, Yossi Sarid made from the podium of the Knesset, and subsequently wrote in a newspaper: "The Akedah was a crude prank; I don't like these kind of jokes. If God wanted to test Abraham, it would have been better not to involve children. . . . I am unable and unwilling to criticize Abraham as a father, but I refuse to recognize him as a symbol and role model." 15

\section{“Internal" Criticism: Midrash and Liturgical Poetry}

Criticism of the Akedah did not begin in the twentieth century. One example of an early critique can be found in the introduction to the chapter on the Akedah in Bereshit Rabbah (55:3). The section beginning with the verse from Ecclesiastes (8:4), “inasmuch as a king's command is authoritative, and none can say to him, 'What are you doing?" contains more than a hint of censure.

Objections to both the command and the deed itself can also be found in early liturgical poetry from the Land of Israel. In her article, "Did Abraham Sin by Binding Isaac?" ("He-hata Avraham Avinu be-Akdo et Yitzhak?"), Shulamit Elizur presents examples of liturgical poetry from the fifth century CE that rebuke God for commanding Abraham to sacrifice his son. ${ }^{16}$ The most striking of these is the poem "Kedushta Le-Shavuot" by Rabbi Eleazar Kallir, in which the Torah itself criticizes Abraham: "He forgot that God is like a father who has pity on His children/He should have pleaded for mercy!"

About two hundred years after Kallir, and apparently in his footsteps, Yohanan HaKohen, a Palestinian Jewish poet wrote, "But he should have pleaded before Him and begged for mercy/ in order to save his only son from the coals of the fire." Abraham should have pleaded for mercy on behalf of his son, but he did not. ${ }^{17}$ 


\section{Maimonides, Kierkegaard, and Rav Kook}

The story of the Akedah both troubled and fascinated the Danish philosopher Søren Kierkegaard all his life. ${ }^{18}$ This passion inspired him to write a fictional description of the critical moment at which Abraham turns to slaughter his son: "Then for an instant he turned away from him, and when Isaac again saw Abraham's face it was changed, his glance was wild, his form was horror. He seized Isaac by the throat, threw him to the ground, and said, 'Stupid boy, dost thou then suppose that I am thy father? I am an idolater. Dost thou suppose that this is God's bidding? No, it is my desire." 19

According to this imaginary reenactment by Kierkegaard, Isaac, terrified, turns to God and begs for mercy: "If I have no father upon earth, be Thou my father!" Abraham says silently to himself, "O Lord in heaven, I thank Thee. After all it is better for him to believe that I am a monster, rather than that he should lose faith in Thee." In this incredible narrative, Kierkegaard brings to life the full horror that lies at the heart of the Akedah. ${ }^{20}$

Kierkegaard offers two answers to the ethical question: (1) During the Akedah a temporary, ad hoc suspension of morality occurred (the "teleological suspension of the ethical"); (2) God never intended for there to be a sacrifice and Abraham was also certain that this was not his intention. Kierkegaard's first answer in effect follows the line of thought of Maimonides, Nachmanides, and Rashi. His second answer, shared by other modern thinkers, deviates from the straightforward meaning of the verses that praise Abraham for his willingness to sacrifice that which was most precious to him.

In The Guide of the Perplexed, Maimonides reveals his awareness of the ethical difficulty and aberration from nature inherent to the Akedah, and uses this issue to argue that this was an exceptional case. ${ }^{21}$ Future generations must absorb its underlying principle but not imitate the practice. It is worthwhile to note his definition of the act as something that "one would not imagine that human nature was capable of it ... that which is repugnant to nature." In other words, this act is contrary to the ways of nature. The crux of the ethical difficulty lies not in the harm caused by a father to his son but in Abraham's unique situation: the fact that he was childless, that the child arrived after a period of despair, and that in performing the deed he was destroying all he had hoped for-that his descendants would become a nation serving God. Maimonides, in his time and place, was prepared to make peace with this singular aberration for the sake of a worthy goal. 
While Maimonides praised the Akedah as a singular occurrence constituting an example that must be emulated and followed, Yeshayahu Leibowitz went to the other extreme and argued that the Akedah represents the negation of human values. ${ }^{22}$ According to Leibowitz, the essence of the service of God in its entirety is "Akedatic." Every performance of a commandment done for its own sake without ulterior motives "represents the motivation animating the Akedah." Leibowitz distinguishes between a "religion of values" and a "religion of commandments":

The religion of values and beliefs is an endowing religion-a means of satisfying man's spiritual needs and of assuaging his mental conflicts. Its end is man, and God offers his services to man. A person committed to such a religion is redeemed man. A religion of Mitzvoth is a demanding religion. It imposes obligations and tasks and makes of man an instrument for the realization of an end which transcends man. ${ }^{23}$

In contrast to Leibowitz, Rav Abraham Isaac ha-Kohen Kook refused to negate human values and argued in several places that it is impossible for faith to contradict natural ethics. ${ }^{24}$ Rav Kook discussed the Akedah in several places. In a letter to Moshe Zeidel, he explained that the Akedah provides a necessary distinction between vibrant religious fervor that allows and even compels child sacrifice, and the purification of the religious sensibility in preparation for the prohibition of child sacrifice ("a deep-seated addiction to idolatry... that overcame even the mercy of the parents and made cruelty to their sons and daughters into a permanent fixture of the worship of Molech"). It was necessary to put Abraham to this test in order to persuade the surrounding society that in its purification and cleansing, the religious sentiment that now recoils from child sacrifice has not lost its fervor; it continues to burn and is profoundly ready for sacrifice. ${ }^{25}$

In his commentary on the Akedah in his prayer book, Olat Ra'aya, Rav Kook explains that Abraham journeyed to the Akedah in a spirit of enthusiasm and personal commitment: "This holy old man did not walk with stooped shoulders or failing strength toward this incredible act of worship that lies in contrast to all the behaviors inherent to man's inner nature. He walked upright, at full height and at full strength.” This description reflects Kierkegaard's words, "for thou didst gain all and didst retain Isaac. Was it not so? Never again did the Lord take him from thee, but thou didst sit at table joyfully with him in thy tent." ${ }^{26}$ It appears that many thinkers have been profoundly influenced by the awe of a modern man, a non-Jew, at Abraham's stamina during his trial. 


\section{The Akedah and Contemporary Thought}

In our generation, the Akedah has become a touchstone for philosophical and political opinions on topical subjects in Israeli society and the religious world. Rabbis Shagar, Yoel Bin Nun, Yuval Cherlow, Yehuda Brandes, Shlomo Aviner, and Yaakov Ariel, as well as professors Chana Safrai, Avi Sagi, and Binyamin Ish-Shalom are all similar in that their approaches to the Akedah, and their ways of resolving its difficulties correspond naturally to their general perspectives regarding matters of Torah and faith. The following survey demonstrates this succinctly.

Yoel Bin Nun and the "Double Source" Approach

Yoel Bin-Nun argues that Rav Kook never considered the possibility that "Abraham should have protested, screamed all night, asked difficult questions about the promises that had been made to him or, in particular, cried out that it was entirely impossible that God would want human sacrifice-as the Torah of Moses makes clear (Deut. 12:31)." However, Rabbi Bin-Nun acknowledges that "with all of the personal, human, and ethical difficulty in accepting this interpretation, it must be conceded that in the language of the verses describing the Akedah there is nothing to even hint at a fundamental opposition to the command in the opening verses, and Rav Kook's analysis does not in any way contradict the verses themselves." The solution that he offers correlates with the thesis of his book as a whole-the concept of the "double source" as a comprehensive model for understanding the thought of Rav Kook. This original solution accepts the paradox of the call to refrain from sacrificing Isaac and the call to perform it. According to Rabbi BinNun's approach to understanding Rav Kook, both of these voices were heard simultaneously. ${ }^{27}$

\section{Avi Sagi: Religion and Ethics}

Avi Sagi's study of the Akedah forms a part of his larger discussion of the questions surrounding conflicts between Judaism (halakhah, Torah) and contemporary morality. In the introduction to his book Judaism: Between Religion and Morality (Yahadut: Bein Dat u-Musar), he presents the two fundamental questions that form the basis of his research: First, according to the philosophic and halakhic tradition, is morality determined by religion? Second, is there a normative contradiction between religious and ethical imperatives ${ }^{28}$ He offers three potential models for answering these questions. The first is 
dependence - morality is determined by religion, and thus there is, in fact, no conflict. The second is conflict-dissonance is elevated to the status of a religious principle (Leibowitz). The third model is the development of exegetical tools that will reconcile religious and ethical imperatives. If Judaism had adopted one of the first two models, the winding exegetical and halakhic path through which the Jewish tradition has met these challenges would have been unnecessary. The existence of this exegetical path reconfirms both the existence of autonomous morality and the rejection of normative conflict as a religious ideal. This autonomy was concisely expressed by the sages in the meta-halakhic principle, "her ways are pleasant ways" (based on Prov. 3:17), understood by the rabbis as a rule dictating that all halakhic legal decisions must conform to standards of morality. In the words of the Radbaz (Rabbi David ibn Zimra), "It is written 'her ways are pleasant ways' and the statutes of our Torah must agree with reason and logic." ${ }^{29}$ Sagi concludes by noting that "the moral of the Akedah appears at its conclusion-the principle that the believer is meant to derive from the Akedah is the harmony between religion and morality." 30

\section{Rabbi Shagar and the Principle of the Empty Space}

Fundamental philosophical thoughts are naturally imprinted with the personality and basic positions of the thinker. Because of its depth and the intensity of the questions that it raises, the Akedah reflects the innermost beliefs of the many thinkers who have studied it. To paraphrase the well-known expression, it can be said, "Tell me how you understand the Akedah, and I will tell you your standpoint within the contemporary religious world."

Rabbi Shagar, for example, based his entire outlook on the principle of the "empty space." 31 The issues that occupied his spiritual world were questions of faith in a world that had lost its certainties. The modern world that knew the truth gave way to a postmodern world in which no truth takes precedence other another. His understanding of the Akedah reflects this basic position. He disagrees with Maimonides' position that the Akedah is proof of the truth of prophecy and emphasized instead the uncertainty of faith: "A conceited and all-knowing religious position turns the idea of a religious test, and with it all religious endeavor, into fiction. A spiritual trial in particular and religious life and genuine connection to God in general exist only within a humble personality, content not to be known."32 From this perspective, we are all "bound on an altar" in that we live in a time of uncertainty and are asked nonetheless to believe in God and follow his ways. ${ }^{33}$ 
Rabbi Yuval Cherlow also maintains that contemporary believers are "bound." However, unlike Rabbi Shagar, ${ }^{34}$ he does not interpret the Akedah as a state of comprehensive uncertainty, but rather a specific uncertainty connected to the ethical difficulty inherent in the Akedah itself. As Jews who do the will of God even when we do not identify with it, we sacrifice our individuality. According to Rabbi Cherlow, who deals extensively with the relationship between ethics and Judaism, we, modern believers, are the sacrifices bound for slaughter, "struggling to understand the Akedah but nonetheless binding our inner will to the altar of our service of God. We bind our inner worlds and sacrifice them on the altar." 35

Safrai, Brandes, and Ish-Shalom: Educating for Freedom of Choice and Critical Thinking

Chana Safrai grappled with the question of the Akedah and morality by radically shifting the focal point of the story. ${ }^{36}$ The heart of the trial does not lie in the question of whether Abraham would follow the command but "whether Abraham would object to the terrifying order as he did regarding Sodom." From this she concluded that "the believer must distinguish between the commands that he receives.... The call of the angel, 'Do not raise your hand against the boy' is well placed at the center of the story and serves as a clear message to refrain from all human sacrifice - of children or adults - out of pure faith." She concludes that "in this way, the story of the Akedah becomes a renewed asset in a thinking religious environment - a story worthy of being read on the Days of Awe, days of soul searching and examining our stance before God." 37 This commentary contains a beautiful message, in which Safrai reveals her contemporary religious outlook and her critique of a certain type of religiosity that is, among other things, uncritical. It is, however, difficult to find support for her interpretation in the simple meaning of the verses. $^{38}$

In an article that focuses on the educational-existential aspect of the Akedah, Rabbi Yehuda Brandes ${ }^{39}$ proposes three educational goals that will inculcate the legacy of the Akedah: (1) emulating the spiritual greatness of the Patriarchs, (2) dedication and self-sacrifice, (3) action accompanied by critical thinking and skepticism. The learner must be alerted to the positive and negative aspects of each goal. Appreciating the greatness of the Patriarchs can produce a feeling of personal insignificance, while dedication and self-sacrifice can result in moral insensitivity. Critical thinking and skepticism can weaken stamina and motivation, because it is difficult to live and function in a state 
of doubt. This open, enabling, and flexible approach is characteristic of the thought and educational methodology of the author.

The approach of Binyamin Ish-Shalom is fundamentally different. ${ }^{40} \mathrm{He}$ consciously chooses one approach over another and thus reveals his ideology and social agenda. He raises two alternative possibilities for the focal point of the story: the commandment "offer him there as a burnt offering" (Gen. 22:2) or the order "do not raise your hand against the boy" (22:12). According to Ish-Shalom, only the second possibility is meaningful to the contemporary reader and thus educationally viable: "Rav Kook wrote that fear of heaven must not suppress natural human morality. . . . I would like to call upon us all to come together and learn the Torah anew, from its foundations, and establish as a basic principle and starting point that human life, the existence of the Jewish people, and feelings of solidarity and mutual responsibility take precedence over any other values."

Rabbis Shagar, Cherlow, and Brandes, and Professors Ish-Shalom and Safrai-all expressed the conscious choice of a meaningful and value-based, existential-philosophical (or educational) approach to the Akedah, without however adhering to the peshat (simple) meaning of the verses.

\section{The Akedah as Reflected in Israeli Literature: For or Against the Akedah as a Political Act}

But I am not sand on the beach

And I do not keep the promises that God gave to Abraham

(Hanoch Levin, “The Land that God Promised to Abraham”)

Professor Hillel Weiss argues that acceptance of the Akedah is correlated to acceptance of Zionism, while a rejection of one involves the rejection of the other. In two important studies, he points out varying contradictory trends in the use of the Akedah in twentieth-century Hebrew literature. ${ }^{41}$ Weiss claims that acceptances of the Akedah grants us an aspect of immortality, while its rejection endangers our uniqueness and existence as a people: "Rejection of the Jewish Akedah leads inevitably to the rejection of the Zionist Akedah." 42 In his book Portrait of a Fighter: Studies on Heroes and Heroism in Contemporary Hebrew Narrative Fiction (Diukan ha-Lohem: Iyunim al Giborim u-Gevura be-Siporet Ha-Ivrit shel ha-Dor ha-Aharon), Weiss surveys how twentieth-century Jewish writers used the Akedah. He quotes from Agnon as an example of an author who saw belief in the Akedah as tantamount to belief in the unique 
destiny of the Jewish people: "From where do we derive this strength, that every day we are killed and slaughtered and bound on an altar and wounded, and we accept it all in love and do not consider ourselves to be superior to others?" 43 Weiss points out a paradox-death that revives: "The choice of death, as a concept, and commitment to it, revives. The acceptance of the yoke of the Akedah is what grants us eternity." ${ }^{44}$ Weiss attacks contemporary secular Israeli critics of the Akedah-for example, Aharon Megged, who wrote the following lines: "No, he shouldn't have died. He was sacrificed on the altar. You remember the story of the Binding of Isaac: the father, Abraham, takes his son, his only son whom he loves, and offers him up on Mount Moriah. That's how it was. Exactly. But no angel." ${ }^{45}$ Weiss uses Uri Zvi Greenberg to illustrate the shallowness of the new generation in coping with the challenges facing them.

In his article "Comments on the Binding of Isaac" ("He'arot le-Akedat Yitzhak"), Weiss condemns both contemporary education for teaching that nothing is worth dying for and contemporary literature as "protest literature that does not fight but gives in to its own self-pity and pseudo-existentialist self-expression." ${ }^{6}$ With regard to the Akedah he explains that "as soon as we reject the way of the Akedah, we condemn ourselves to an annihilation that is the result of the recognition that life had become so shallow that it disappeared altogether." 47

Like the rabbis and educators whose approaches I described above, Weiss overlooks the peshat level of the verses. However, in contrast to the others, in the heat of the political-ideological battle, he concedes too easily regarding the real ethical issues lying behind the voices rejecting the Akedah.

\section{The Akedah in the Context of its Own Time: The Removal of the Ethical Onus from Abraham}

Up to this point I have pointed out an obvious phenomenon: most of the interpretations of the Akedah are rooted in the environment of the commentator: in the place, time, and culture in which he or she lived, as well as in his basic system of beliefs. I would now like to apply this approach to Abraham himself. The interpretation that I would like to propose here-understanding Abraham's position in light of his contemporary cultural background-is not new. Atheists and Bible critics continue to use it to completely invalidate the ethical mores of the Bible as "primitive" and incompatible with the spirit of modern "enlightenment." Nonetheless, I would actually like to propose this 
approach from a faith-based perspective. I argue not only that it is plausible, but that, in fact, contemporary Bible readers have a moral and educational obligation to examine Abraham and his reaction to the trial of the Akedah against the backdrop of his historical period.

I will begin by explaining the basis of this argument. The biblical world in which Abraham heard God's call was fundamentally different from the modern world. For a member of an ancient agricultural culture that revolved around the fruit of the land, the commandment of the Akedah fits along the spectrum of difficult, but bearable, commandments in which man is required to offer to God the most precious fruit of his labors, as tithes and tenth-parts, first shearings, first fruits, and firstborn animals. Though child sacrifice appears on the extreme end of this spectrum, it is nonetheless on the spectrum. In the surrounding culture, the demand to sacrifice a child was a harsh demand, yet a legitimate and plausible one. This was a culture entirely devoid of the awareness of a child's inherent right to life and dignity. Simple proof of this can be found not only in the deplorable practices of the idol worshippers, such as the sacrifice of children to Molech, but also in the commandments concerning the Hebrew servant girl, a very young girl sold into slavery (Exod. 21:7), and the verse "a blessing on him who seizes your babies and dashes them against the rocks!" (Ps. 137:9). The argument that there is a significant difference between taking human life and the sacrifice of an animal, or offering the fruits of the field is disputable in a world where children were perceived as extensions of their parents rather than independent beings. In the ancient world, a child was considered to be merely a part of his father, like one of the organs of his body; if he were to be commanded to sacrifice an organ (as in the case of Bar Kokhba's soldiers), he would, with difficulty, comply. According to this perspective, the subject of the test, the one who sacrifices the most in the Akedah, is the father, not the son. ${ }^{48}$

In The Bible according to Its Simple Meaning (Ha-Mikra ke-Peshuto), Arnold Ehrlich describes the ancient custom, common in neighboring cultures, of placing a newborn immediately after birth on the knees of the head of the family, who would decide whether or not to let the infant live. Though this custom does not appear in Jewish sources, it is alluded to in several verses in the Torah that describe children as "born upon the knees of" a certain individual:

In ancient times, the life of the newborn depended upon the will of the father. After its birth the infant was placed on the ground at the feet of 
its father. If the father left him there, he would die, and if he picked him up, he would live... Job refers to this practice when he says, "Why were there knees to receive me" (Job 3:12), because if his father's knees had not received him, he would have died immediately after birth. This is also the meaning of the verse, "the children of Machir son of Manasseh were likewise born upon Joseph's knees" (Gen. 50:23). ${ }^{49}$

God did not ask Abraham to sacrifice his wife, or his brothers, or his parents. The command to sacrifice his son, in the time period in which Abraham lived, and in light of his surrounding culture, was a harsh command, but a comprehensible one. The very request itself demonstrates that it was worthy of being heeded and that the contemporary culture allowed it to be heeded. The great innovation lay in the message: ram-yes; human sacrifice-no. Abraham could not understand the extent of this innovation as we can in our time. He was only able to comprehend it in the context of his time and place (cows and sheep-yes; people-no). The concept of the rights of all people, including women and children, to life and dignity, would, in a few thousand years, be derived from this idea. As I have said, Abraham's trial was a test of devotion and readiness to go the extra, and most difficult, mile.

The subject of the Akedah is not Isaac. It is Abraham who was tested, who was asked to forfeit that which was most dear to him. Critics of the Akedah who argue for the superiority of the crucifixion, in which the sacrifice offered himself, not his son, have missed this crucial point. ${ }^{50}$ The potential loss of his son in the Akedah was infinitely more difficult and painful for Abraham than the loss of his own life.

In this type of world, God tested Abraham in order to draw a line between the sacrifice of crops and animals, and that of humans. ${ }^{51}$ In the culture in which Abraham lived, this was a very fine line. In our culture, in part as a result of the moral outlook created by the Torah, this line is very clear, unequivocal, and easy to discern. The difference between these two lines is the crux of the argument in this paper. It is impossible to compare Abraham to a contemporary person placed in the same situation, because the attitude to offspring in the culture in which he lived was, as I have said, radically different. In other words, when God turned to him and asked him to sacrifice his beloved son, Abraham heard a difficult, although reasonable, request. Sending Ishmael to meet his fate in the desert was also not easy and can be found on the same spectrum. ${ }^{52}$ 


\section{The Children of Sodom}

It is important to note for whose lives Abraham pleaded and for whose he did not. The question of the existence or absence of righteous men in Sodom does not solve the problem of the killing of young children who had not sinned. ${ }^{53}$ Why didn't Abraham, the fighter for justice, plead for the lives of the children of Sodom? The answer is obvious: in Abraham's world, in the reality of his time, there was no basis, either conceptual or practical, for the idea that children are beings separate from their parents. The physical and economic dependence of young children on others was a fundamental concept in the ancient world, and the basis for the way they were treated. The biblical term for young children, taf, is apparently derived from the word tafel meaning "subordinate," and connected to tapil meaning "parasitic"; in other words, dependent upon a primary figure for sustenance and survival.

As I argued at the beginning of this article, the Akedah is only an example of a larger phenomenon. We can apply the same approach to other commandments that are difficult for us to accept today, such as the biblical laws of marriage and divorce, among others.

The danger inherent in this approach is clear. The major concern is that placing Abraham in the context of his time and place makes him irrelevant as an educational role model. This would undermine the traditional Jewish approach that regards the saintly Patriarchs as timeless role models to be learned from and emulated. A number of the articles in this collection discuss these questions in depth. ${ }^{54}$ Tamar Ross devoted a large part of her book, Expanding the Palace of Torah: Orthodoxy and Feminism, to similar questions related to the sanctity of the Torah and its commandments, and the transience or timelessness of the word of God. ${ }^{55}$ In the chapter entitled "The Word of God Contextualized: Successive Hearings and the Decree of History," she attempts to answer these questions by means of the concept of "accumulating revelation," based on the theology of Rav Kook and others. According to this idea, the ethical and cultural development of the world is part of perennial divine participation in the transmission of the Torah and its changing interpretation throughout the generations.

While the dangers are great, so are the possibilities. By placing Abraham in his time and culture, the Akedah can once again be read, as it always was and will be, as a parable for eternal human devotion to God. The biblical Akedah will continue to be a metaphor for the immolation of both the human will (or consciousness, or understanding) and body, as in the Holocaust and the 
wars of the State of Israel, in which mothers and fathers sent their sons to defend their people and their land.

The subtle distinctions between the transience or timelessness of the Torah raised in this discussion of the Akedah, and their application to other difficult passages, can lead to a more complete and harmonious acceptance of the eternal message delivered to us, by means of human and historical channels, in the Torah of Moses.

\section{Endnotes}

I would like to thank the readers of the article for their helpful comments: Rabbi Yehuda Brandes, Dr. Tova Ganzel, and Dr. Yoshi Fargeon

1. An enormous amount of material has been written about the Akedah. I have made use of the following sources (a mere "tip of the iceberg") in writing this article: Uriel Simon and Ruth Calderon, eds., "Akedat Yitzhak be-Mikra, be-Midrash, be-Piyut, be-Shira ha-Ivrit ha-Hadasha u-be-Omanuyot" [The Binding of Isaac in the Bible, midrash, liturgical poetry, Hebrew poetry, and art] (Tel Aviv: Alma College, 1999); Israel Rosenson and Binyamin Lau, eds., Akedat Yitzhak Lezaro: Mabat me-Ayin Yisra'elit [The Binding of Isaac for the sake of his descendants: An Israeli perspective] (Tel Aviv: Yitzhak Hirschberg Memorial Foundation, 2003). Many other sources, both academic and theological, on the story of the Akedah can be found in Yoshiyahu Fargeon, Lamah Tetanu ha-Shem: Meuravuto shel Elohim be-Shekarim u-be-Hatayu'ot be-Sipur ha-Mikra'i [Why, O Lord, do you lead us astray? God's involvement in lying and deception in the Biblical narrative], PhD diss., Bar Ilan University, 2014, 108-127. For a survey of approaches to the Akedah over the course of time, see Alexander Even Chen, Akedat Yitzhak be-Parshanut ha-Mistit ve-ha-Filosophit shel ha-Mikra [The Binding of Isaac in the mystical and philosophical interpretation of the Bible] (Tel Aviv: Miskal, 2006). The website for the daily study of the Bible www.929.org has added new texts to the literature dealing with the contemporary struggle to understand the Akedah. These can be found on the page for Genesis chapter 22: http://www.929.org.il/chapter/22.

2. See Sara Japhet, "Nisayon ha-Akedah ve-Nisayon Iyov: Mah Beneihem?" [The trial of the Akedah and the trial of Job: A comparison], in Iyov: be-Mikra be-Hagut u-be-Emunot [Job in the Bible, in thought, and in belief], ed. Lea Mazor (Jerusalem: Magnes, 1995), 13-33. Japhet rejects the perception of Abraham as a role model and a paradigm in his willingness to perform the sacrifice. In her eyes, his decision should not be taken as an example for future generations.

3. Daniel Vainstub, "Korbonot Adam be-Cana'an ve-Yisrael" [Human sacrifice in Canaan and Israel], Beer-Sheva 19 (2010):117-181. Vainstub surveys the archaeological findings that testify to the existence of the practice and in an appendix to his article he brings postbiblical sources attesting to a similar practice, including Clearchus, Quintus Ennius, and others. One of his central arguments is that the practice was introduced to the Land of Israel and became pervasive there during the reign of Josiah.

4. Ibid., 180. For more on the subject of the Akedah and child sacrifice in the Bible see the first two chapters of Jon D. Levenson, The Death and Resurrection of the Beloved Son: The Transformation of Child Sacrifice in Judaism and Christianity (New Haven: Yale University Press, 1993), 3-35. Levenson argues for the existence of a biblical tradition supporting 
human sacrifice alluded to in various verses including "You shall give Me the firstborn among your sons" (Exod. 22: 28), inter alia.

5. Jerusalem Talmud, tractate Ta'anit, $2: 4$.

6. In some sources, the name of the mother is not mentioned, and in midrash Eikhah Rabbah she is called Miriam bat Tanhum. There is a huge difference between the story of Hannah and her Seven Sons and the Akedah. Hannah, like her fellow Jews who sacrificed their lives throughout the generations, had no choice, whereas Abraham did. This is the crux of the enormous ethical challenge raised by his deed.

7. A. B. Yehoshua, "Levatel et ha-Akedah al yidei Mimusha" [To negate the Akedah by actualizing it], in Be-Kivun ha-Negdi: Kovetz Mekharim al Mar Mani shel Alef Beit Yehoshua [In the opposite direction: A collection of articles about Mr. Mani by A. B. Yehoshua], ed. Nitza ben Dov (Tel Aviv: Hakibbutz Hameuchad, 1995), 394-398. On the profound influence of the Akedah on several of Yehoshua's important stories, see also: Mordechai Shalev, "Hotem ha-Akedah" [The impact of the Akedah], in Be-Kivun ha-Negdi, 399-447. A. B. Yehoshua recently published a long article summarizing his approach to the Akedah and offering an alternative reading. See A. B. Yehoshua, "Me-Mitos le-Historia" [From myth to history)], January 19, 2015, http://www.929.org.il/author/150/post/678.

8. Yehoshua, "Levatel et ha-Akedah al yidei Mimusha," 396.

9. "I wanted to create within the book a real Akedah story that would be actualized in the very place that the biblical story takes place, with one essential difference: what was in the biblical story only a threat would become here a horrible reality. By means of the murderous realization of the threat perhaps I would succeed in removing the magic, and even the soul, of this seminal story. I call this 'negating the Akedah by actualizing it." Ibid., 396.

10. On Kierkegaard, see further below.

11. He explains the Akedah as a manipulation by Abraham who founded a new religion and feared that his son would forsake it. In attempting to ensure its continuation, he staged the binding of Isaac on the altar, and at the last moment dropped the knife and said to his son, "The God that I believe in forbade me to kill you. He saved your life!"

12. Hugo Bergmann, "Ha-Shamayim ve-ha-Aretz" [Heaven and earth], in Ha-Akedah ve-haAdam shel ha-Yom (Tel Aviv: Sifre, n.d.), 21-28. "Man is able and even obligated to critically analyze even sacred texts when they conflict with his logical and, in particular, his ethical understanding" (25).

13. Asa Kasher, "She-bakol dor va-dor: shalosh akedot" [In every generation: three Akedot], in Yitzhak Lezaro, 127-133.

14. For a comparison of the model of the Akedah to the model of Absalom and David, see Yair Zakovitch, "Ha-Ayil be-Sevakh ve-Avshalom be-Sovekh" [The ram in the thicket and Absalom in the branches], Tarbiz 52 (1983): 143-144; and Marc Bregman, "Temunat ha-Ayil be-Tziur ha-Akedah be-Ritzpat ha-Pesifas me-Beit Alfa" [The picture of the ram in the depiction of the Akedah in the mosaic at Beit Alfa], Tarbiz 51 (1982): 306-309.

15. Yossi Sarid, "Yitzhak Hayy o Meit" [Isaac living or dead], Yediot Aharonot, 1989. Another quote: "The Akedah is something that riles me to no end from the depths of my soul, as does Masada." (From a debate in the Knesset, December 27, 1983.)

16. Rosenson and Lau, eds., Akedat Yitzhak Lezaro, 215-224.

17. Ibid. Tzadok Ha-Kohen (19th cent.) argued that Abraham should have refused, and on this he was tested. His interpretation does not conform to the peshat of the verses that praise Abraham.

18. The critique of Kierkegaard, a non-Jew, is "internal"; in that he was a religious man who accepted the veracity of the Bible. 
19. Søren Kierkegaard, Fear and Trembling, trans. Walter Lowrie (Princeton: Princeton University Press, 1941), 27.

20. Kierkegaard, Fear and Trembling, 27. Years later A. B. Yehoshua would continue in this direction and imagine his own version of the Akedah, similar to Kierkegaard's in its depiction of Abraham's deceit and lies intended to preserve his son's faith, but different from it in essence. In contrast to Kierkegaard the believer, Yehoshua, who has declared himself to be a nonbeliever, is not familiar with, or does not understand, the fervor of religious faith.

21. Moses Maimonides, The Guide of the Perplexed, 3:24.

22. Yeshayahu Leibowitz, Judaism, Human Values, and the Jewish State, ed. Eliezer Goldman (Cambridge: Harvard University Press, 1992), 119, 122.

23. Leibowitz, Judaism, Human Values, 14.

24. For example, Rav Abraham Isaac Ha-Kohen Kook, Shemoneh Kevatzim [Eight collections], ed. She'ar Yashuv Cohen and Dov Schwartz (Jerusalem: n.p., 1999), kovetz b-102; published also in Rav Abraham Isaac Ha-Kohen Kook, Orot (Jerusalem: Mosad Harav Kook, 2005), 140.

25. Igrot Ra'aya [The letters of Rav Kook] (Jerusalem: Mosad Harav Kook, 1985), 2:43.

26. Kierkegaard, Fear and Trembling, 37. Rabbi Shlomo Aviner's discussion of the Akedah in Akedat Yitzhak Lezaro (135-138) is influenced by this amazing description of Abraham who succeeds in maintaining both his faith and devotion to God as well as his natural paternal feelings for his son.

27. Yoel Bin-Nun, Ha-Makor Ha-Kaful: Hashra'a ve-Samkhut be-Mishnat ha-Rav Kook [The double source: Human inspiration and authority in the philosophy of Rav Kook] (Bnei Brak: Hakibbitz Hameuchad, 2014), 177-187.

28. Avi Sagi, Yahadut: Bein Dat u-Musar [Judaism: between religion and morality] (Tel Aviv: Hakibbutz Hameuchad, 1998), 11-12. This book, which discusses the relationship between religion and morality in Judaism, is the continuation of his previous book on the subject of religion and morality in general.

29. Responsa of the Radbaz 1:52: 627. Cited in Sagi, Yahadut, 155-156.

30. Sagi, Yahadut, 266.

31. Shimon Gershon Rosenberg, "I-Vada'ut ke-Nisyon ha-Akedah" [Uncertainty as the test of the Akedah], in Nehalech Be'ragesh [We walk in fervor: Selected works of Rabbi Shimon Gershon Rosenberg-Shagar] (Alon Shvut: Institute for the Writings of HaRav Shagar, 2010), 111-124.

32. Rosenberg, "I-Vada'ut ke-Nisyon ha-Akedah,” 120.

33. For further elaboration see the article by Etan Abramowitz, "Havnayat ha-Subiekt ha-Ne'ekad” [Structuring the bound subject], January 2, 2012, http://alimletrufa.blogspot. co.il/2012/01/blog-post_02.html.

34. And Yeshayahu Leibowitz (see above), who turned the observance of the commandments in general into an "Akedah": an act lacking reward, done only for its own sake.

35. Akedat Yitzhak Lezaro, 89. See also his article at the beginning of the book.

36. Ibid., 140-141.

37. Ibid., 146.

38. Compare with the statement of Sara Japhet (note 2 above). Japhet does not discuss Abraham's ethical dilemma but focuses instead on the change that God undergoes in the course of the Akedah as God negates once and for all the need for human sacrifice.

39. Akedat Yitzhak Lezaro, 91-102.

40. Ibid., 150. 
41. Hillel Weiss, Diukan ha-Lohem: Iyunim al Giborim u-Gevura be-Siporet Ha-Ivrit shel ha-Dor ha-Aharon [Portrait of a fighter: Studies on heroes and heroism in contemporary Hebrew narrative fiction] (Ramat Gan: Bar Ilan University, 1975), 222-230; Hillel Weiss, "He'arot le-Behinat 'Akedat Yitzhak' be-Siporet ha-Ivrit Bat Zemanenu Ke-Topos, Tema u-Motiv” [Notes on the study of the Binding of Isaac in contemporary Hebrew literature as topos, theme, and motif], in Ha-Akedah ve-ha-Tokhehah: Mitos, Temah u-Topos be-Sifrut [The Binding of Isaac and the Rebuke: Myth, theme, and topos in literature], ed. Zvi Levy (Jerusalem: Magnes, 1991), 31-52.

42. Weiss, Diukan ha-Lohem, 231.

43. From his story "Lefi ha-Tza'ar ha-Sakhar" [The reward is in proportion to the effort], in Ha-Esh ve-ha-Etzim [The fire and the trees] (Jerusalem: Schocken, 1978), 5-19.

44. Weiss, Diukan ha-Lohem, 225.

45. Aharon Megged, The Living on the Dead, trans. Misha Louvish (London: Jonathan Cape, 1970), 247.

46. Weiss, Diukan Ha-Lohem, 225.

47. Ibid., 226.

48. This point was missed altogether by critics such as A. B. Yehoshua. See above.

49. Arnold B. Ehrlich, Mikra Ki-Peshuto [The Bible according to its literal meaning] (New York: Ktav, 1969), 84.

50. As pointed out earlier, A. B. Yehoshua prefers the Christian ethos of self-sacrifice to the biblical ethos of the Akedah.

51. Jephthah who sacrificed his daughter (Judg. 11) did not grasp this distinction.

52. Despite what I wrote above, it is possible that the attitude toward women in Abraham's time is also part of this phenomenon. (Abraham handed Sarah over to Abimelech and Pharaoh, and sent Hagar away.)

53. I would like to thank my friend Shulamit Kislev for calling my attention to this important point.

54. For example, the papers of Ben Sommer and Tamar Ross, especially subsections 18-19 of the article of the latter.

55. Tamar Ross, Expanding the Palace of Torah: Orthodoxy and Feminism (Hanover, N.H.: Brandeis University Press, 2004), 184-186, 204-207. It is important to note Uriel Simon's viewpoint in this context. In Bakesh Shalom u-Radfehu: She'elot ha-Sha'a be-Or ha-Mikra, ha-Mikra be-Or She'elot ha-Sha'a [Seek peace and pursue it: Topical issues in the light of the Bible, the Bible in the light of topical issues] (Tel Aviv: Miskal, 2002), he proposes the adoption of a historical-developmental approach to biblical commands that we find difficult to accept in light of our modern ethical awareness. He distinguishes between "static eternity," in which the words of God remain frozen in their place, and "dynamic eternity," meaning that "the word of God preserves its essential core while it adapts to the changing needs of each generation" (260). 